\title{
FORMATION OF RHETORICAL SKILLS IN SCHOOL: MENTAL FEATURES AND ACTIVE TEACHING METHODS
}

\author{
Anastasiia A. Korshunova \\ Kazan Federal University, Kazan, Russia \\ Elena M. Bastrikova \\ Kazan Federal University, Kazan, Russia
}

Sholpan K. Zharkynbekova

L.N. Gumilyov Eurasian National University, Nur-Sultan, Kazakhstan

Kuralay B. Urazayeva

L.N. Gumilyov Eurasian National University, Nur-Sultan, Kazakhstan

Karlygash S. Abylkhassova

L.N. Gumilyov Eurasian National University, Nur-Sultan, Kazakhstan

E-mail: anastasiiakorshunovarussia@gmail.com

Recepción: 05/08/2019 Aceptación: 16/09/2019 Publicación: 23/10/2019

\section{Gitación sugerida:}

Korshunova, A.A., Bastrikova, E.M., Zharkynbekova, S.K., Urazayeva, K.B. y Abylkhassova, K.S. (2019). Formation of rhetorical skills in school: Mental features and active teaching methods. 3C TIC. Cuadernos de desarrollo aplicados a las TIC. Edición Especial, Octubre 2019, 180-193. doi: https://doi.org/10.17993/3ctic.2019.83-2.180-193

\section{Suggested citation:}

Korshunova, A.A., Bastrikova, E.M., Zharkynbekova, S.K., Urazayeva, K.B. \& Abylkhassova, K.S. (2019). Formation of rhetorical skills in school: Mental features and active teaching methods. 3C TIC. Cuadernos de desarrollo aplicados a las TIC. Special Issue, October 2019, 180-193. doi: https://doi.org/10.17993/3ctic.2019.83-2.180-193 


\section{ABSTRACT}

The presence of more than twenty directions in Russian rhetoric is based on a different understanding of the effectiveness of communication. Common is the understanding of the effectiveness as an overall criterion of rhetoricalness - nonrhetoricalness speech communication. This article considers the formation of rhetorical skills in the American and Kazakh schools on the example of the study of literature in a non-native language - didactic prose of Leo Tolstoy. The article analyzes the active methods for the formation of rhetorical competence of the student in the American school, for the schools of Kazakhstan with non-Russian language of education, forecasts of active tasks on the same didactic prose of Tolstoy are offered. These scenarios of designing lessons are explained by the identification of commonality and differences in the formation of rhetorical competence. The solution of such issues is made in the article: an attempt to understand whether the recommendations for the formation of rhetorical skills in the American and Kazakh schools with non-Russian language of education are common, is there a connection with mental differences. To answer this question types of speech activity, argumentation technique, critical thinking, empathy, receptive and productive activity in the classroom (reflection) were analyzed. Comparison of teaching non-native literature in American and Kazakh schools with non-Russian language of education is based on the application of such experience in social life and the formation of students' motivation to study. The establishment of commonality and differences in the formation of effective communication skills allowed to understand the role of mental characteristics of students, the impact of national psychology of students in Kazakhstan on the cognitive and metacognitive scaffolding. The use of the same types of speech activity - listening, speaking, reading, writing - showed the dominance of speaking in the school in Kazakhstan.

\section{KEYWORDS}

Rhetoric, Effective communication, Secondary school, Second (non-native) language, Russian literature, National psychology, Mental characteristics of students. 


\section{INTRODUCTION}

The formation of rhetorical competence at school and university implies the skills of free speaking, the ability to accurately reproduce someone's speech, authentic broadcast own thoughts to the addressee of the message, the ability to build communication, prevent / solve disputes. This is how the effectiveness of communication characterized (Kachesova et al., 2018).

In this article the problem of the text interpretation at literature lessons is on the focus of view. Leaning on the provisions, provided by hermeneutic scientists, the authors regard the interpretation as a special dialogue between the reader and the text. The issue is also devoted to the problem of individual learning styles formation based on the psychological characteristics of the reader-student, the types of his representative system (auditory, visual or kinesthetic). Based on the facts found identified according to the experiment authors have developed the idea of forming individual ways for learning literature (Golikova et al., 2016; Kheirabadi \& Mirzaei, 2019; Córdova-Rangel et al., 2017).

The problem of interest in reading for integrated school lessons by means of visual practices is considered by scientists of the Kazan school (Vakhrameeva et al., 2016; Andrianova et al., 2017; Kashisaz \& Mobarak, 2018). The authors showed a steady decline in interest in reading in Russia, as was observed in many countries around the world. The article proposes an approach to increase interest in reading by illustrating. The authors believe that the integrated lessons of literary reading and drawing contribute to the immersion in a literary text, and visual language more understandable for the perception of students of the elementary school than the abstract language of literature.

Selection of authentic texts and methods of work with them are important in the study of literature in the second language. The authors of the experimental work aimed at the use of the effective ways of teaching communicative competencies to the full-time and part-time first-year students learning foreign languages at the language department by means of the novel «The Moon and Sixpence», written 
by the prominent English writer William Somerset Maugham, consider that this approach helps to form the communicative competence of students (Varlamova et al., 2016; Subich et al., 2016; Eslami \& Ahmadi, 2019; Kondubaeva et al, 2018).

In this sense, interest was caused by the planning of lessons in the American school in the study of Russian literature on the material of didactic prose by Leo Tolstoy, in textbooks for 7, 8, 10 classes and in 11-12 classes in the textbook "World literature" publishing "McDougal Littell" (Applebee, 2008a; 2008b; 2008c; 2008d).

The purpose of the article is to establish commonality and differences in the American and Kazakh schools in the development of effective communication skills, as well as to identify the relationship between the national psychology of students and the impact on active teaching methods in the school in Kazakhstan.

\section{METHODS}

The authors of the considered textbooks define didactic literature as "literature intended mainly for the purpose of explaining or conveying a moral message" (Applebee, 2008c). Accordingly, the understanding, analysis and interpretation of instruction, morality in the works of Leo Tolstoy are the main strategies of semantic reading.

In order to arouse interest in the work, much attention is paid to the stage of "challenge" . Therefore, before studying the short story "The old grandfather and his little grandson" (grade 8), the question is: "How well do we treat elder?" And for the understanding of key ideas pro-extermination questions can be specified (Applebee, 2008b). This sets the context of reasoning and activates the mechanism of empathy. Usage of the mechanism on the example of studying a non-native (second) language on the example of students of non-linguistic specialties in universities in Kazakhstan is described in the articles of the authors of this article (Abylkhassova, 2019; Birjandi \& Jazebi, 2014; Jabbari et al., 2019). 
In the study of literature in a second language by the authors of the widely used ways of raising intercultural dialogue. Hence, it appeals to the method Comparing Theme. It builds a comparative study of the short story of Leo Tolstoy, written on the basis of folk tale, and the Japanese folk tale "The wise old woman", retold by Yoshiko Uchida. The method Comparing Theme develops students ${ }^{6}$ understanding of the term universal theme as an understanding of the unity of the world cultural process, activating intercultural dialogue as an object and tool of learning. The method Literary Analysis becomes the basis of the guiding strategy for the formation not only of the socio-cultural context of the study, but also of rhetorical culture (Applebee, 2008b; Nakhaee \& Nasrabadi, 2019).

Receptive activity is also provided by the task List it. After reading the text, the transition to reflection is also a step-by-step system. First, it is the understanding and interpretation as the ways to monitor the speech competence of students and their rhetorical culture, which are carried out at the stage After reading. Therefore, while studying the short story "The Old grandfather and his little grandson" Comprehension is accomplished by defining Recall, whereas Writing for Assessment suggests a cognitive scaffolding (Birjandi \& Jazebi, 2014; Barzamini, O. (2018). Cognitive scaffolding is offered to Read the prompt.

It is interesting how the authors differentiate the activities of students and direct them to progression. The recommendation Plan your writing teaches the operations and procedures of thinking, working with the table Points of Comparison, which sheds light on the proposed in the tutorial plan essay.

The connection reading with writing is through Reading strategy: it is important to set a purpose for reading. That is how the term universal theme is achieved.

Differentiation of student activity is supported by the task Draft your response. Methods of comparing the passage from the new Testament and Tolstoy's story are divided into a number of operations that determine the content of each part 
of the essay: introduction, body, conclusion. As a test of the correctness of judgments, understood in the rhetorical aspect as persuasiveness, the stage of Revision is proposed (Applebee, 2008c).

Channels of information perception in the study of literature in a non-native language achieve efficiency by working with visibility. For example, the authors use the Analyze visuals in order to better understand the text when studying the story "The old grandfather and his little grandson" (Applebee, 2008b).

It is necessary to pay attention to how the motivation for reading is caused by the heading Author online, where in the biography and literary destiny of the writer the emphasis is made on the secret of his popularity and world recognition.

\section{RESULTS AND DISCUSSION}

Kazakhstan is a country of natural bilingualism. From the 2017-18 academic year, the reform of secondary education is announced here. The widespread introduction of the communicative-activity approach has led to the updating of the content of all textbooks. For the study of literature in a non-native language, the important role of active methods was determined by the proximity of didactic methods, the role of empathy, changing the educational paradigm, with the strengthening of the role of skills, critical thinking, the ability to apply the knowledge in life, etc.

In the present part of the development of active tasks on the same material didactic prose by Leo Tolstoy. However, the focus of based on the context of cognitive scaffolding with different mental - Kazakhstan (not Kazakh) environment.

Here, under the stage of "challenge", before studying the story "The Old grandfather and his little grandson" communication with personal experience of students in a society with strong patriarchal values, deep rooted household of Islam, elders' piety, the actual tasks associated with a description of the signs of 
old age. While in the American school of reasoning about the reasons for respect for old age require the involvement of texts of another culture (Japanese folk tales) with an emphasis on universal for the peoples of the world theme.

Attention to the problematic issues that require a detailed answer in a society with pronounced etiological attitudes (to the listener) require the activation of speaking. Therefore, it is recommended as answers that require a detailed answer: "Why did grandfather keep silent?", "What lesson did the boy learn from this story? How does this action to characterize the personality of the hero?" and giving the answer by the personal relation.

The formulation of personal attitudes, opinions as a strategy of personalityoriented approach is due to the cognitive setting, guiding the student with independent work on the story: "Formulate the moral of the story. What are the signs of didactic prose" to reflection - "Write a story about your grandfather or grandmother, or about such grandfather and grandmother they would like to be seen".

The difference between the tasks completing the study of the story in the societies of American and Kazakh culture is obvious. At the heart of reflection, producing the same rhetorical competence are different ways of argument.

We are close to the experience of commented reading and analysis of the authentic fictional text by A.P. Chekhov by philological students in the classes of Russian as a foreign language described in one of the articles of teachers of Kazan Federal University. The authors consider: «Foreign students learn about the culture and perception of the Russian people, expand their vocabulary and improve their communication skills through working with the literary text, so it is important to choose an appropriate pedagogical approach» (Valeeva et al., 2018).

The argument of the American student is aimed at the universality of the topic, which is obvious for Kazakhstan initially. The shift of the discursive core of the argument to the reputational value of senior members of the family in a society with a traditional minority structure (when the heir is the younger son, and he 
also in a traditional family takes care of the parents) is a model of behavior, contains ready-made patterns of behavioral type. At the same time, the social contradictions that have affected the traditional society are also known to students. The reflection, which is carried out in the course of independent work, makes it possible to correct the existing socio-cultural stereotypes of the institution of the family, opening the horizons of their potential change based on a comparison of the real and possible worlds.

In the national school of Kazakhstan, during the dictionary work, preference is given to such types of work: the formulation of a certain sentence in other words, the selection of synonyms, work with the meanings of words with the help of a dictionary, work with the methods of word formation to understand the semantics, explanation with the help of examples of the meanings of idioms, phraseological phrases, self-identification of signs of style. Attention to the search for information using electronic resources to compare the native culture and the studied contributes to the understanding of unity and national identity. For example, commenting on the cases of different laughs in the Russian language and native, students are imbued with an understanding of the sound symbolism of the native language, in Kazakh, for example, the relationship between the signifier and the signified gave rise to an abundance of ideophones with their sound semantics (Khusainov, 1988). One of the common ways' students explain the meaning of words is a contextual approach.

The transition to productive activities defines as new approaches reflection, allowing students to formulate the moral of the story, and - respectively - to determine the genre characteristics of didactic prose.

\section{SUMMARY}

Comparison of teaching non-native literature in American and Kazakh schools with non-Russian language of instruction is based on the application of such experience in social life and the formation of motivation of students to study. 
The establishment of commonality and differences in the formation of effective communication skills allowed to understand the role of mental characteristics of students, the impact of national psychology of students in Kazakhstan on the cognitive and metacognitive scaffolding.

The use of the same types of speech activity - listening, speaking, reading, writing - showed the dominance of speaking in the school of Kazakhstan.

Different contents of argumentation, different operations of critical thinking, different forms of inclusion of empathy, receptive and productive activity at a lesson are revealed.

\section{CONCLUSIONS}

The commonality of didactic approaches in the formation of rhetorical competence in the American and Kazakh schools with non-Russian language is revealed in the following:

- Using the visual channel as a conscious perception and processing of information as an activating basis for writing an essay;

- Inclusion of empathy in the context of reasoning by modeling educational situations involving personal social experience;

- Attitude to the argument as a sign of rhetorical competence of the student;

- Connection of cognitive and metacognitive scaffolding with historical, cultural and social context of the studied literature.

Commonality can be traced and the mechanism of motivation to read. This is the content of the columns containing a brief information about the writer as a system of entertaining facts that explain the recognition and reputation / fame / popularity in the world. 
The differences are due to the predominant passive type of perception of information in the Kazakh national school due to the formation of several centuries of etiological attitudes to the role of the listener. Hence the main differences in didactic approaches:

- Accentuation of problematic issues that require a detailed answer in order to enhance speaking in the Kazakh school;

- Orientation in the argument on the mental characteristics of students, the basic values of the ethnic group;

- Priority design of brainstorming in the pro and contra systems, protection of opinions and correction of the opponent's worldview in the process of argumentation.

The main difference lies in the strategy of the dictionary work. In the American school, it involves the ability to build communication, prevent / resolve disputes, identify communication errors and see the causes of these errors, while in schools of Kazakhstan in teaching a second language is a priority to expand the vocabulary.

\section{AKNOWLEDGEMENT}

The work is performed according to the Russian Government Program of Competitive Growth of Kazan Federal University. Article is written within the framework of the project "Formation of a new type of professional multilingual personality in the conditions of multilingual education in Kazakhstan" under the contract N. ${ }^{\circ} 132$ from "12" March 2018. 


\section{REFERENCES}

Abylkhassova, K. (2019). Formation of reading literacy in US schools. Current experience for updating Kazakhstan textbooks. The III All-Russian scientificpractical conference «Pedagogical education: optimization, modernization and development forecastr. Moscow: RUDN.

Andrianova, N. S., Nizamieva, L. R., Nazarova, G. I., Ostroumova, O. F., \& Leblanc, C. (2017). The Development of Students' Cognitive SelfStudy While Teaching Reading in FL Training. Fournal of History Culture and Art Research, 6(5), 321-326. doi: https://doi.org/10.7596/taksad.v6i5.1258

Applebee A. N. (2008b). "Literature (Grade 8). Student textbook", Austin, Texas: McDougal Littell, 1067 p.

Applebee A. N. (2008c). "Literature (Grade 10). Student textbook", Austin, Texas: McDougal Littell, 1209 p.

Applebee A. N. (2008d). "World Literature. Student textbook", Austin, Texas: McDougal Littell, 1379 p.

Applebee A.N. (2008a). "Literature (Grade 7). Student textbook", Austin, Texas: McDougal Littell, 999 p.

Barzamini, O. (2018). An Analytical Review of Civil Liability in Mines, a Look at the Explosion of the Winter Yoart of Azadshahr city. UCT Journal of Social Sciences and Humanities Research, 6(3), 8-15.

Birjandi, P., \& Jazebi, S. (2014). A comparative analysis of teachers' scaffolding practices. International Fournal of Language and Linguistics, 2(3), 154-164. doi: https://doi.org/10.11648/j.ijll.20140203.14

Córdova-Rangel, A., Escalera-Ghavez, M. E., \& Gasca, S. B. (2017). Mathematics really generates anxiety? Empirical Study in middle school students. International Electronic Journal of Mathematics Education, 12(1), 8897. Retrieved from https://www.iejme.com/article/mathematics-reallygenerates-anxiety-empirical-study-in-middle-school-students 
Eslami, R., \& Ahmadi, S. (2019). Investigating the Role of Educational Media on Secondary School Students' Learning Process Improvement in Jahrom City. Fournal of Humanities Insights, 3(01), 13-6. doi: https:/ / doi.org/10.22034/ jhi.2019.80890

Golikova, G. A., Zamaletdinov, R. R., Vafina, A. H., \& Mukhametshina, R. F. (2016). The "New" Strategy in Teaching Literature in a Multiethnic Environment (as exemplified by the Republic of Tatarstan). International fournal of Environmental and Science Education, 11(6), 1237-1246. Retrieved from https:/ / eric.ed.gov/?id=EJ1114295

Jabbari, E., Charbaghi, Z., \& Dana A. (2019). Investigating the Effects of Educational and Motivational Education at Different Levels on the Performance and Application of dart throwing. Fournal of Humanities Insights, 3(02), 37-44. doi: https://doi.org/10.22034/jhi.2019.80896

Kachesova, Y., Klink, E. I., Kopnina, G. A., Kukueva, G. V., Lukashevich, E. V., Urazaeva, K. B. ... \& Shmakov, A. A. (2018). Rhetoric. The educational book for a magistracy in the direction / specialty "Philology" in universities in Russia and Kazakhstan. Retrieved from http:/ / elibrary.asu.ru/ handle/asu/6562

Kashisaz, S., \& MobarakI, E. (2018). The Effects of Private Education Institutes in Providing Modern Financial Knowledge in Developing Countries. Fournal of Humanities Insights, 02(04), 172-178. doi: https://doi.org/10.22034/ jhi.2018.80887

Kheirabadi, M. A., \& Mirzaei, Z. (2019). Descriptive valuation pattern in education and training system: a mixed study. Fournal of Humanities Insights, 3(01), 7-12. doi: https://doi.org/10.22034/jhi.2019.80889

Khusainov, K. (1988). Sound visualization in the Kazakh language (2nd ed.). AlmaAta, Nauka Publisher.

Kondubaeva, M. R., Bekalay, N. K., Aubakirova, A. K., Ongarbaeva, A. T., \& Tolkinbayev, A. K. (2018). The problem of correctness and reliability of the study in trilingual education. Opción, 34(85-2), 517-543. 
Nakhaee, J., \& Nasrabadi, M. A. (2019). Strategies for Research-Centered Education of Architectural Designing by Examining the Research-Centered Activities of the Top Universities. Fournal of Humanities Insights, 3(02), 50-6.

Subich, V. G., Shangaraeva, L. F., \& Zakirova, L. R. (2016). Improvement of the English language communicative competencies by means of authentic texts. Fournal of Language and Literature, 7(2), 257-261. doi: https://doi. org/10.7813/jll.2016/7-2/48

Vakhrameeva, T., Emanova,J., \& Yao, M. (2016). Forming interest in reading for integrated school lessons by means of visual practices. International fournal of Humanities and Cultural Studies (IFHCS). Retrieved from https://www.ijhcs. com/index.php/ijhcs/article/view/2598

Valeeva, D. R., Ershova, A. A., \& Latypova, E. (2018). Short Stories Of AP Chekhov About Child's World On The Lessons Of The Russian Language As A Foreign ("Grisha"," An Incident"," Children"). Modern Fournal of Language Teaching Methods, 8(10), 320-326.

Varlamova, M. Y., Bochina, T. G., \& Miftakhova, A. N. (2016). Interactivity in teaching a foreign language. The Language Learning Journal, 7(3), 190-194. doi: https://doi.org/10.1080/09571736.2014.994183 